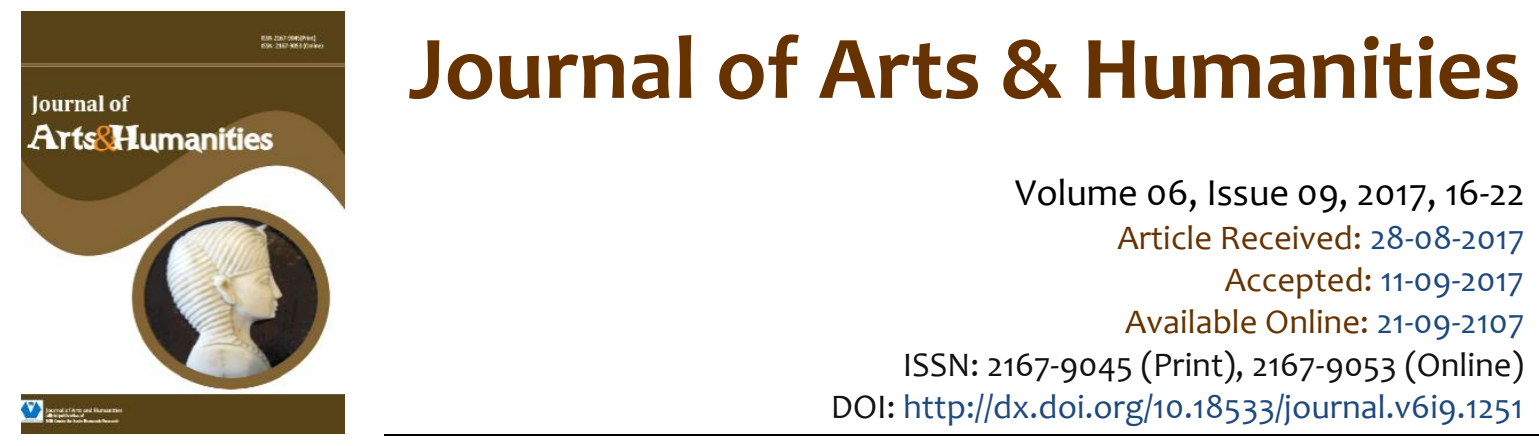

\title{
Out of Time, Out of Place: Primitivism and African Art
}

\author{
Meredeth Turshen'
}

\begin{abstract}
This article debates the proposition that artistic production mirrors humanity's maturation from primitive superstition to scientific rationality. This effort sits at the intersection of demography, political economy and aesthetics. According to traditional demographic theory, primitive peoples are caught in a poverty trap of high birth rates, a condition inimical to industrialization, well-planned urbanization, universal education, women's emancipation and cultural production. The analysis focuses on three dynamics: the demographic effects of mass migration on creativity: the trajectories of declining populations and their places in cultural hierarchies; and slavery and colonialism's reduction to penury of skilled artists in pre-industrial societies. The method interrogates selfreinforcing trends of the canons of demography, political economy and aesthetics and the resulting concurrence on the path of progress, which assumes that art is a reflection of liberal historical advancement. The overarching argument of the article is that by setting the criteria and suppressing alternative accounts of the history of African art, these canons narrow and misrepresent our global cultural legacy. Background: sub-Saharan African art is classified as "primitive" according to the canons of art history, demography and political economy. This label is problematic because it conveys faulty demographic assumptions about sub-Saharan Africa and reflects the ways in which theories of human progress reinforce analyses underlying the designation of primitive. The proposition advanced is that these canons narrow, suppress alternative accounts of the history of African art, and misrepresent our global cultural legacy.
\end{abstract}

Keywords: African Art, Art History, Demography, Primitivism.

This is an open access article under Creative Commons Attribution 4.0 License.

\section{Introduction}

The classification of sub-Saharan African art as "primitive" motivates my exploration of cultural production as it is influenced by the canons of art history, demography and political economy. The question is not simply why some art historians, museums and galleries continue to designate African art as primitive; ${ }^{2}$ the question also explores the ways in which that label conveys common demographic

\footnotetext{
${ }^{1}$ Professor, E.J. Bloustein School of Planning and Public Policy, Rutgers University, USA. Email: turshen@rutgers.edu

${ }^{2}$ It is important to note that the term primitive art is currently in use. For example, Pace Primitive describes itself as a tribal art gallery that maintains an inventory of museum-quality African and Oceanic art (http://www.paceprimitive.com retrieved 30 July 2017).
} 
assumptions about sub-Saharan Africa, and the ways in which theories of human progress reinforce analyses underlying the designation of primitive. The unique importance of the study derives from the implications for museology and world culture in an age of globalization.

I discuss the canons' apparent accord that sub-Saharan African art is out of time, in both the literal sense (we cannot date accurately the work in most museum collections) and the figurative sense (the art is identified as prehistoric, which means it belongs to a timeless period of oral tradition). Similarly we experience sub-Saharan African art as out of place, in the figurative sense of lost context (due to the ways in which much of the material was collected during the colonial era) and in the literal sense of geographical displacement (removal of artifacts to public museums and private collections in the global North).

The article begins with a description of primitive art history, and then discusses African art and African demography; in the third section it turns to issues of style and quality, and concludes with a discussion of the 1984 exhibition called "Primitivism" in $20^{\text {th }}$ Century Art: Affinity of the Tribal and the Modern.

\section{2. $\quad$ Primitive art history}

Why did H.W. Janson, in his influential, widely used and popular History of Art, ${ }^{3}$ first published in 1962 -- the date by which half of Africa had attained independence from colonial rule -- classify subSaharan African art as primitive? In the third edition $(1986)^{4}$, using examples from the $12^{\text {th }}$ through the $20^{\text {th }}$ centuries to illustrate his text, Janson ${ }^{5}$ placed his brief survey of sub-Saharan African art in a section on Primitive Art in Part One, The Ancient World. In Chapter One (Magic and Ritual—the Art of Prehistoric Man), Primitive Art followed the discussion of the New Stone Age (From Hunting to Husbandry). Chapter Two surveys Egyptian art from 3000 to 500 BCE (with no links to Nubia or mention of conquered African lands to the south). Thus for more than thirty years students were exposed to Janson's analysis of subSaharan African art as primitive.

In the opening paragraph of the section on Primitive Art Janson declares, "Modern survivors of the Neolithic ... include all the so-called primitive societies of tropical Africa, the islands of the South Pacific, and the Americas" (Janson, 1986, p. 35). Janson uses the term primitive as "a convenient label for a way of life that has passed through the Neolithic Revolution but shows no signs of evolving in the direction of the "historic' civilizations" (p. 35) By "historic" Janson means civilizations with a written record, overlooking the $6^{\text {th }}$ century Garima Gospels of Ethiopia and the $12^{\text {th }}$ century Timbuktu manuscripts of Mali, many of which are illustrated. He continues, "The entire pattern of primitive life is static rather than dynamic, without the inner drive for change and expansion that we take for granted in ours" (p. 36). These views dovetail neatly with liberal evolutionary theory, which vindicates the view that the course of artistic production follows the emergence of literate civilizations from hunter/gatherer communities. Artistic production in this perspective mirrors humanity's maturation from primitive superstition to scientific rationality.

The earliest examples Janson shows are an Ife portrait (one of the $12^{\text {th }}-13^{\text {th }}$ century sculptures that were unearthed in Nigeria in 1938) and a Benin bronze (one of the hundreds of $15^{\text {th }}$ and $16^{\text {th }}$ century sculptures, which were confiscated by the British in a raid on Benin City, Nigeria, at the end of the $19^{\text {th }}$ century). All of the other examples of sub-Saharan African art date to the $19^{\text {th }}$ and $20^{\text {th }}$ centuries. Prevailing liberal evolutionary theory sanctioned Janson's assertion that Ife and Benin sculptures are primitive rather than examples of what might more accurately be called classical African art. To give Janson's statement some context, in the early $16^{\text {th }}$ century, when Michelangelo was expressing his "sense of kinship with Classical [Greek] sculpture" and creating David (1501 - 1504), carvers in the Kongo Kingdom were creating exquisite ivory oliphants (and both were known to the Apostolic Palace); yet Janson (1986, p. 451) praises Michelangelo as a "genius of divine inspiration" and makes no mention of

\footnotetext{
3 More than four million copies in fifteen languages have been sold (https://en.wikipedia.org/wiki/H._W._Janson retrieved 4 August 2017).

4 I use the third edition (1986) in this article. The subsequent edition (1991) made minor changes (the word ethnographic was substituted for primitive). In the fifth (1995) and sixth (2001) editions the section on Primitive Art was suppressed altogether. Thereafter the work was retitled History of Art: The Western Tradition.

5 H.W. Janson died in 1982; his son, Anthony Janson, expanded and edited the third edition, but he did not revise the text on primitive art. I continue to refer to the author as H.W. Janson.
} 
the Kongo ivories. Nor do museums exhibit such $16^{\text {th }}$ century creations side by side, generally relegating African art to ethnographic collections. ${ }^{6}$

Liberal evolutionary theory is not the only canon that supports primitive art history. Demography, the study of statistics that illustrate the changing structure of human populations, also judges subSaharan African societies.

\section{African art and African demography}

Demographers working with African data focus first on fertility rates, which are considered too high, and second on mortality rates, which were also high but began to fall as AIDS claimed so many lives (UN, 2012). The third component of demography--migration--has generally been left to historians of Africa, except for current concerns with rapid urbanization and the African refugee crisis in Europe. The canon of demography--predominantly demographic transition theory--reinforces primitive art history by positing that a normative model of low birth and death rates (the European equilibrium) is synonymous with high productivity, a rational dependency ratio (the number of working adults to dependent children and elderly), and sustainable development. According to this theory, Africans are trapped in poverty by high birth rates, which are inimical to industrialization, rational urbanization, universal education, women's emancipation, and cultural production.

Two aspects of demography in particular are critical to understanding 19 th and $20^{\text {th }}$ century subSaharan African art: first, the relation of population size to cultural production, and second, the importance of migration to the history of African art making.

First, to understand cultural production--the quantity and quality of work--we need basic demographic information on the tribes that are named as originators. The example used here of the Kota peoples of Gabon is taken from Janson (1986, p. 38) who devotes an extensive discussion to two reliquaries--Kota protective guardian figures called mbulu ngulu that were carved, covered with strips of copper or brass and set upon baskets of relics. The two guardians illustrated are similar (the facial expressions vary, one is convex, the other concave), which provokes Janson's comment that "Given the rigidly conservative nature of primitive society, we can hardly believe that the ancestor cult of the Bakota underwent any significant change during the time span that separates" the creation of the two figures (1986, p. 38). Note that in liberal evolutionary theory rigidity is associated with traditional societies, and flexibility - the capacity to adjust continuously to change - with modernity. Janson admits to being unable to date the figures, to not knowing which of the two was created first, or what the time elapse between them might be.

The peoples grouped under the Bakota comprise one of Gabon's smallest tribes (about 27,796 in 1970 [Perrois, 1970, p. 23]), which must have affected their ability as subsistence farmers in the rain forest to support full-time artists. Compare the Bakota reliquaries with Janson's next illustration, a Baluba kneeling woman from the Congo. The Baluba, who numbered about 5.6 million in the late $20^{\text {th }}$ century, were members of the Luba Empire, which flourished from the late $15^{\text {th }}$ through the late $19^{\text {th }}$ century. The wealth and relative stability of the Luba Empire supported courtly art with commissions given to skillful artists (Roberts, 2013). ${ }^{8}$ In the absence of mechanized agriculture, population size mattered to both survival and cultural production.

Primitive art history, as demonstrated in museums and gallery exhibitions, pays little attention to the changing demographics and political organization of African societies. African social and political organization demonstrate enormous variety: large-scale and centralized states or small-scale and village societies, the former often densely settled and the latter sometimes widely scattered; settled, nomadic

\footnotetext{
${ }^{6}$ The Nelson A. Rockefeller collection, assembled in 1956 in the Museum of Primitive Art, is the precursor of Department of the Arts of Africa, Oceania, and the Americas at the Metropolitan Museum of Art in New York; the collection is displayed in a separate wing of the museum.

7Janson (1986, p. 38) is mistaken about Kota history; he says "European travelers, so far as we know, did not begin to bring back any Bakota guardians until the eighteenth century." European references identifying the Kota, who began migrating from central Africa to Gabon in the $18^{\text {th }}$ century, date to the 1870 s (Siroto, 1968). Christian missionaries entered the area in the early 1900 s to convert the Kota, destroying many of the art objects associated with their traditional religion. If this is a typographical error and Janson meant the $19^{\text {th }}$ century, it is not corrected in the fourth edition of the book.

${ }^{8}$ This figure from northeastern Luba-related peoples is characteristic of works by the so-called Buli Master, the first identified workshop and still among the most celebrated in all of Africa (Roberts, 2013).
} 
or hunting and gathering societies; peoples with long histories of migration or those less connected to the larger world. Without demographic and political information art historians cannot know how these societal differences affected cultural production.

Population size matters to primitive art history for another reason: the smaller the tribe, the harder it is to reconstruct the past. The Kota funerary statues have survived a culture that has disappeared, their meaning forgotten by remaining members of the population (Chaffin \& Chaffin, 1979; Perrois, 1976). Small groups were often assimilated, even before Christian missions and colonial administrations worked to annihilate their traditions. In contrast, large and populous West African kingdoms supported griots who maintained a tradition of oral history.

The most significant way in which demography figures in sub-Saharan African art is in the impact of migration. The slave trade (across the Atlantic, the Sahara and the Indian Ocean) was the largest forced migration in world history. It severely disrupted and reshaped the demographic regimes and social reproduction of African societies for a millennium, robbing African households of an estimated 30 million young women, men and children (Cordell, 2013). In the $19^{\text {th }}$ century, one of every two Africans was held in slavery (Cordell, 2013). What happened to the skills of African artists between 1500 and 1950? How was cultural production affected by the loss of population through the slave trades, through colonial wars of conquest that destroyed the great kingdoms, ${ }^{9}$ and through colonial rule, which imposed grueling forced labor regimes ${ }^{10}$ and dismantled and reassembled thousands of tribal groups? ${ }^{11}$

Some answers to these questions are to be found in studies of political economy that address changing art markets, commissioning and workshops in which young apprentices were trained. An underlying question - that of style - links political economy to primitive art history and, at the same time, encompasses demographic change, in particular the migration of people.

Style

Primitive art historians assume that style is closely linked to ethnic identity, an assumption that cannot be proved (Kasfir, 1984). As in anthropology, the tribal group is the unit of analysis, and the ethnographic present is the time frame for identifying and labeling art objects (Kasfir, 1984). The dominant paradigm is the "one tribe-one style" model, which derives not from art history but from anthropology, and which holds that each style is particular to a single tribe (Kasfir, 1984). Much has been written about style and there is much to say, but for our purposes the concern is with aspects of style linked to political economy and demography. In the first instance I return to the concept of tribe, which carries as many pejorative connotations as does the concept of primitivism.

The references above to the slave trades, colonial wars of conquest, forced labor regimes and tribal reorganization imply that African societies were highly mobile. In addition to the export of slaves, domestic slavery ${ }^{12}$ was widely practiced: for example, slaves were employed in the cultivation of export crops far from their natal villages (Howard, 2006). Migration was not an exclusively male phenomenon: African women were enslaved far from home, and they also migrated, sometimes long distances, for marriage. In the colonial era, African men, and in some cases women, moved for a variety of reasons: to fulfill forced labor demands, for military conscription, for contract labor on infrastructure projects, for work in mining and large-scale cash crop production, and, finally, in what has become a massive shift, from rural to urban areas. Throughout Africa, peoples of different heritage met, mixed and married; and they were often multilingual. Given this history, ethnic purity cannot be part of the definition of tribe. The placement of artwork within a tribal boundary, like the concept of a singular style attributable to each tribe, is questionable on empirical grounds.

\footnotetext{
9 Of all the pre-colonial kingdoms of Congo - Luba, Lulua, Lunda, Mangbetu, Shi and Yaka-only the Kuba survived. The rest disappeared between 1880 and1917 (Vansina 2007).

10 Labor quotas supplied male and female workers to plantations, mines, infrastructure projects, and the armed forces.

${ }^{11}$ Colonial administrations amalgamated ethnic groups in their efforts to create units of effective local government. The Belgians estimated there were more than 6,000 chieftainships when they took over the Congo in 1908 (Marzorati, 1954); by the 1950s they counted fewer than 400 (Saint Moulin, 2003). In the early 1900s the French colonial administration of Gabon sought to reduce the profusion of peoples in the region; they arbitrarily chose the term Bakota, which encompasses a multitude of peoples (Siroto, 1968).

${ }^{12}$ The term domestic slavery is used to describe the practice of slavery by Africans in Africa; although women predominated, this slavery was not limited to performance of household duties.
} 
Take the Bakota reliquaries as an example once again. Janson (1986, p. 38) analyses two figures in an attempt to understand abstract style in primitive art. ${ }^{13}$

Janson $(1986,38)$ reasons that Figure 1 shown above must date from an earlier period than Figure 2 shown below "since we cannot imagine how its realistic features could have evolved from the spare geometry" of the reliquary pictured below.

Janson (1986, p. 39) thinks that the abstraction resulted from endless repetition in reproducing the "older, more nearly original version" because "[t]he conservative temper of primitive society demanded that every new guardian follow the pattern of its predecessor" (Janson, 1986, p. 39). This assertion begs the question of who originated the style, and its assumptions about tribal incapacity for innovation appear to be a direct product of Western liberal evolutionary theory.

Other conclusions, informed by demography and political economy, might be drawn. Since the Bakota comprise a number of tribes (the Mahongwe and Shamaye in northern Gabon were patrilineal; the Obamba, Bawumbu, Mindassa and Mindumbu in the south were matrilineal [Perrois, 1970]), the two figures might come from different tribes rather than from different time periods. The northern Mahongwe funerary figures (see Figure 3) were distinctly different from reliquaries produced in the south.

Yet other explanations are plausible. Simplification may have reduced the time needed to create the piece and may account for the changes, rather than abstraction. Time restraints in the $19^{\text {th }}$ century may have been tied to Kota mobility: these farmers practiced slash and burn agriculture, which required periodic removal to new farm plots and the heavy, time-consuming work of clearing the forest to create them. In the $20^{\text {th }}$ century the pressures of French colonial labor demands might also have restricted the time (and people) available to carve these funerary figures (Gray \& Ngolet, 1999). Perhaps most importantly, it seems that the Kota attached greater importance to the relics-the skulls and bones of their ancestors - than to the sculptures that adorned the baskets containing them; when families moved they took the bones with them and discarded the figures (Perrois, 1976).

It is possible that the question is not style but quality. Collective judgment of artistic value preserved much of what remains of early European and Renaissance art in churches and cathedrals (Rubin, 1984, p. 21). Most of what the West has preserved of African art is of generally low quality, collected haphazardly by Christian missionaries, colonials, travelers and, after World War I, "runners" who were financed by Parisian art dealers (Rubin, 1984). Much artwork was lost when missionaries routinely destroyed "heathen idols" they regarded as sacrilegious. Aesthetic quality did not determine the selection process. William Rubin (1984) speculates that African sculptors probably hastily made "replacements" for some sacred objects they wanted to protect, or village men, rather than trained artists, made some of the masks brought back to Europe. Until recently, our Fine Arts tradition has not treated tribal art as part of art history; consequently, there was no development of, nor support for, an ongoing critical tradition. The loss of context of much of the material collected during the colonial era,

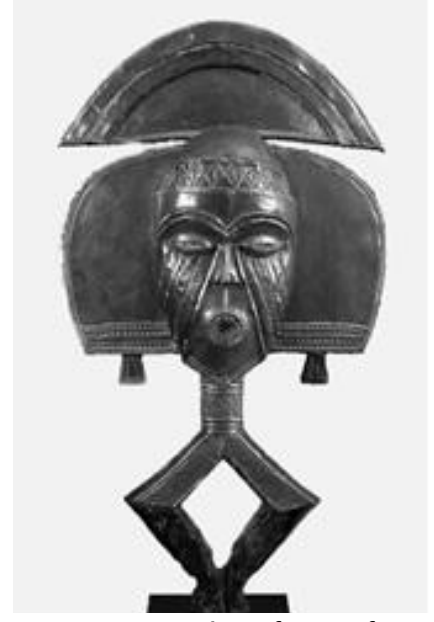

Figure 1: Guardian figure from the Bakota area, Gabon, 19th2oth century. Wood covered with brass and copper.

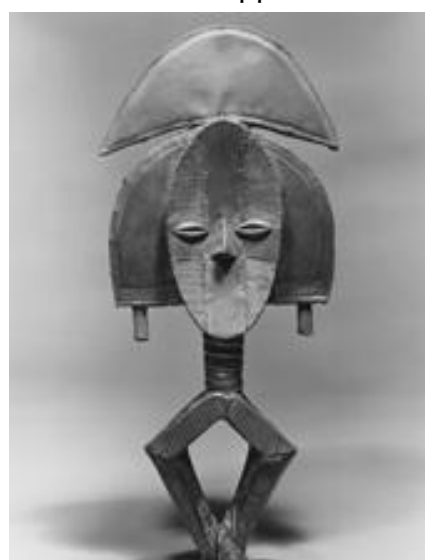

Figure 2: Guardian figure from the Bakota area, Gabon, 19th2oth century. Wood covered with brass and copper.

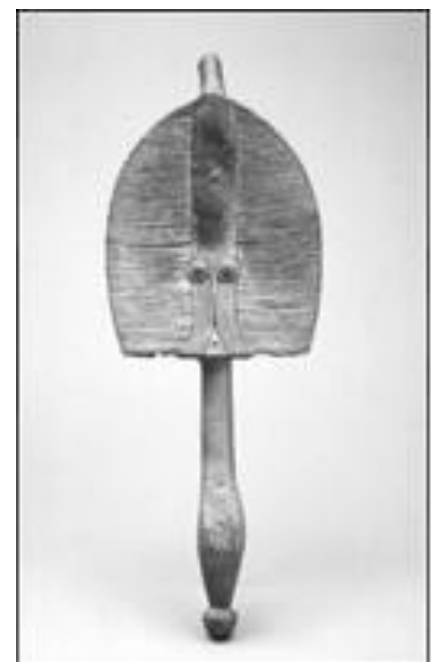

Figure 3: Mahongwe reliquary guardian. Gabon, 19th-20th century. Wood covered with brass and copper.

\footnotetext{
13 These reproductions are from Wikimedia Commons, the free media repository; Figures 1 and 2 closely approximate the original figures in Janson's text but are not the same. Searching through hundreds of images for look-alikes revealed the infinite and subtle variations on the themes.
} 
due to the way art was acquired from its makers and users, compounded the difficulty of establishing a critical discipline.

Quality is subjective. Parisian dealers and the Franco-Belgian hierarchy of preferences stressed highly refined, often intricate workmanship, beautifully polished or patinated surfaces, and a restrained stylized realism (Rubin, 1984). In contrast, many vanguard artists like Picasso, Matisse and Brancusi preferred work that was raw, unfinished, with decorative patterns or designs based on geometric shapes, which they judged as extremely inventive art. Rubin thinks the dealers" "judgments masked an unconscious vestige of the old evolutionary bias that placed the more realistic typologies-those closer in character to Western art and hence also more accessible-at the top of the scale of values" (Rubin, 1984, p. 17).

\section{Primitivism (in conclusion)}

In 1984, the Museum of Modern Art held an exhibition called "Primitivism" in $20^{\text {th }}$ Century Art: Affinity of the Tribal and the Modern. The press release for the exhibit said that few if any external influences on the work of modern painters and sculptors have been more critical than that of the tribal arts of Africa, Oceania and North America. The term "primitivism" (in quotation marks in the exhibition title) was said to be used to describe the Western response to tribal cultures as revealed in the work and thought of modern artists. "Primitivism," Rubin (the exhibit's curator) wrote in the catalogue for the exhibition, refers "not to the tribal arts in themselves, but to the Western interest in and reaction to them. 'Primitivism' is thus an aspect of the history of modern art, not of tribal art (Rubin, 1984, p. 5)." But on $\mathrm{p} .4$ of the MoMA press release, we read this:

[The fourth section of the exhibit presents] a selection of post-1970 Western art that draws its inspiration not so much from tribal objects as from a more conceptualized sympathy with the methods, materials and mentality of Primitive cultures. Structures of myth and cosmology here combine with a primal sense of art-making activity to embody a strongly altered but still vital bond between modern and tribal creation. (Museum of Modern Art, 1984, p. 4, my italics)

At the end of the press release there is a reference to historians of "Primitive art" that undermines Rubin's premise. "Primitive" art, they seem to say, comes from primitive cultures; it is art made by primitives. Rubin's intent is lost to the ubiquitous, pre-established perception of Africans and their art as primitive.

Once again there is an elision of primitivism (a descriptor of style) and primitive (a personal characteristic): primitivism, used to describe an object, is joined together with primitive, used to denote the creator of the object. The talk slides easily from primitive sculptures to primitive sculptors.

The way synonyms for primitivism are used in Fine Arts is revealing of the racial prejudice and bias in art history. Western artists from non-academic backgrounds are routinely described as naïve or they are called folk artists or creators of outsider art. Naïve, folk and outsider are not terms applied to African artists, who remain simply primitives--persons belonging to preliterate, nonindustrial societies or cultures. A euphemism that has come into use in Canada to refer to its indigenous peoples is First Nations; and in France the current terminology in use at the Musée du quai Branly - Jacques Chirac is les arts premiers. The sequestration of tribal culture in ethnographic museums perpetuates its disconnect from the mainstream of art history, and the failure to present coeval world cultures obscures the interaction of societies that took place all over the planet.

As Johannes Fabian (1983) noted, we have persistently treated so-called "primitives" as if they were not our contemporaries but dwelt in some primal time, as if they had no voice except when answering questionnaires we have designed to find out how things were before contact with the West. Most writing about African art overlooks the changes brought by intercultural contact among Africans and between Africans and people from overseas, not only from Europe but also from the Near and Far East. Accounts influenced by anthropological techniques of fieldwork tend to discount or ignore the historical, demographic and power relations of European dominance in modern African history. The designation of African art as "primitive" buttresses the idea of a single African story and tribes, each of which has a single style. This is a distorted, one-dimensional view of Africans that diminishes their history and contributions, sophistication and worldly knowledge, creativity and artistry. 
In summary, this article has critiqued the proposition that artistic production mirrors humanity's maturation from primitive superstition to scientific rationality. By investigating the intersections of demography, political economy and aesthetics, it has revealed the trend in the canons of these disciplines to reinforce one another. The canons concur on the path of progress, leading to the consensus that art is a reflection of liberal historical advancement. The overarching argument of the article is that by setting the criteria and suppressing alternative accounts of the history of sub-Saharan African art, these canons narrow and misrepresent our global cultural legacy. It is my hope that this article will contribute to changes in museums and to experiments in exhibitions so that they reach beyond cultural segregation to cross-cutting displays that explain globalization over the centuries.

\section{References}

Aka-Evy, J.-L. (1999). De l'art primitif à l'art premier. Cahiers d'Études Africaines, 39, Cahier 155/156: 563582. http://www.jstor.org.proxy.libraries.rutgers.edu/stable/4392969

Chaffin, A. \& F. Chaffin (1979). L'art Kota: les figures de reliquaire. Meudon: Alain \& Françoise Chaffin. Cordell, D. D. (2013). Interdependence and convergence: Migration, men, women, and work in SubSaharan Africa, 1800-1975. In D. Hoerder \& A. Kaur (Eds.), Proletarian and gendered mass migrations: A global perspective on continuities and discontinuities from the 19th to the 21st centuries (pp.175215). Leiden: Brill.

Fabian, J. (1983). Time and the other: How anthropology makes its object. New York: Columbia University Press.

Gray, C. \& F. Ngolet (1999). Lambaréné, Okoumé and the transformation of labor along the Middle Ogooué (Gabon), 1870-1945. Journal of African History, 40(1): 87-107. http://www.jstor.org.proxy.libraries.rutgers.edu/stable/183396

Howard, A. (2006). Nineteenth century coastal slave trading and the British abolition campaign in Sierra Leone. Slavery and abolition, 27(1): 23-49. DOI: 10.1080/01440390500499893.

Marzorati, A. F. G. (1954). The political organisation and the evolution of African society in the Belgian $\begin{array}{lll}\text { Congo. African } & \text { Affairs, } & \text { 53(211): }\end{array}$ http://www.jstor.org.proxy.libraries.rutgers.edu/stable/719282

Museum of Modern Art (1984). For Immediate Release: New exhibition opening September 27 at Museum of Modern Art examines "Primitivism" in 2oth century art. New York: MoMA.

Perrois, L. (1970). Chronique du pays Kota [Gabon]. Cahiers ORSTOM Série Sciences Humaines, VII (2): 1568.

Perrois, L. (1976). L'art Kota-Mahongwe : les figures funéraires des populations du basin de l'Ivindo. Arts d'Afrique noire, 20: 15-37.

Roberts, M. N. (2013). The King is a woman: Shaping power in Luba royal arts. African Arts, 46 (3): 68-81. doi: 10.1162/AFAR_a_00089

Rubin, W. (1984). Modernist "Primitivism," an introduction. In W. Rubin (Ed.), "Primitivism" in 2oth c art: affinity of the tribal and the modern (pp. 1-79). New York: Museum of Modern Art, volume 1.

Saint Moulin, L. de (2003). Conscience nationale et identités ethniques: contribution à une culture de la paix. Congo-Afrique : économie, culture, vie sociale, 43 (372): 93-136.

Siroto, L. (1968). The Face of the Bwiti. African Arts, 1(3): 22-27+86-89+96.

UN (2012). Changing levels and trends in mortality: The role of patterns of death by cause. United Nations publication, ST/ESA/SER.A/318.

Vansina, J. (2007). La survie du Royaume Kuba à l'époque coloniale et les arts. Annales Aequatoria, 28: 529. http://www.jstor.org.proxy.libraries.rutgers.edu/stable/25836906 